\title{
ANALISIS KEMAMPUAN PEMECAHAN MASALAH SOAL CERITA HIMPUNAN OLEH MAHASISWA PENDIDIKAN MATEMATIKA FKIP UNIB
}

Hanifah

Prodi Matematika FKIP UNIB

hanifah@unib.ac.id

\begin{abstract}
Penelitian ini bertujuan untuk mengetahui hasil postes dan kemampuan pemecahan masalah soal cerita himpunan oleh mahasiswa. Subjek dari penelitian ini adalah mahasiswa kelas B semester 1 Pendidikan Matematika FKIP UNIB TA 2019/2020 yang berjumlah 33 orang. Instrumen yang digunakan adalah lembar tes, dan angket terbuka. Alat analisisnya adalah tahapan pemecahan masalah menurut Polya yang terdiri dari: 1) Memahami Masalah; 2) Membuat Rencana; 3) Melakukan Rencana; dan 4) Melihat Kembali. Metode atau alur yang digunakan adalah: melaksanakan postes; memeriksa jawaban menggunakan tahapan pemecahan masalah Polya, menghitung prosentase tiap tahapan. Hasil penelitian menunjukkan: Nilai rata-rata hasil postes = 61,82. 21,21 \% jawabannya benar; 6,06 \% jawabannya kosong; 72,73\% jawabannya salah. Bentuk kesalahannya adalah: 48,48 \% salah isi diagram Vennnya; 72,73\% salah operasi himpunannya; dan 36,36\% salah operasi aritmatikanya. Berdasarkan tahapan Polya disimpulkan: 1) Memahami Masalah: ada $66,67 \%$ tidak menuliskan apa yang diketahui; 2) Membuat Rencana: 100 \% tidak menuliskan rumus untuk mengisi diagram Venn; 3) Melakukan Rencana; $100 \%$ menjawab pertanyaan berdasarkan gambar diagran Venn tanpa menuliskan rumusnya; 4) Melihat Kembali; 72, 73\% tidak melihat kembali jawabannya. Disimpulkan bahwa mahasiswa belum terbiasa menggunakan tahapan Polya dalam menyelesaikan soal cerita.
\end{abstract}

Keywords: Kata Kunci : Himpunan, Diagram Venn, Pemecahan Masalah Polya 


\section{Pendahuluan}

Matematika Dasar adalah matakuliah wajib yang ditawarkan di Program Studi Pendidikan Matematika FKIP UNIB dengan bobot 3 SKS. Materi inti yang dibahas pada matakuliah Matematika Dasar adalah Logika dan Himpunan. Kedua materi ini sudah tidak asing lagi bagi mahasiswa karena sudah pernah dibahas di sekolah menengah. Logika diberikan dari awal kuliah sampai UTS, dan Himpunan setelah UTS sampai UAS, dan dosennya berbeda. Tujuan dari matakuliah Matematika Dasar adalah untuk membekali mahasiswa dengan ilmu dasar matematika yang kuat sehingga mahasiswa mempunyai fondasi yang kuat sehingga mampu membangun berfikir kritis mahasiswa. Mampu berfikir kritis sangat diperlukan untuk mempelajari ilmu matematika ditingkat lebih lanjut. Kenyataannya pada pembelajaran ditingkat lanjut seringkali para pengajar mengeluhkan lemahnya materi dasar yang dikuasai mahasiswa.

Pada tanggal 20 Agustus 2019 adalah hari pertama perkuliahan Matematika Dasar. Kami tim pengajar Matematika Dasar sepakat untuk mengadakan pretes tentang Himpunan. Setelah lembar jawaban diolah diperoleh informasi sebagai berikut: Ada 9,09 \% orang tidak membuat diagram Venn. Ada 81,82 \% membuat diagram Venn tetapi isinya salah. Hanya $12,12 \%$ yang menjawab isi diagram Venn dengan benar. Bagaimana cara untuk mendapatkan angka-angka pengisi diagram Venn tidak ditulis oleh mahasiswa. Untuk menjawab pertanyaan mahasiswa juga tidak menggunakan lambang yang dipakai pada himpunan. Soal pretes tersebut dilengkapi dengan pertanyaan "Apakah saudara kesulitan menjawab soal pretes? $24,24 \%$ tidak menjawab, $12,12 \%$ menjawab ya karena lupa, $48,48 \%$ menjawab ya karena tidak paham, $15,15 \%$ menjawab tidak kesulitan, namun tidak dilengkapi dengan penjelasan. Dalam hal ini dapat dikatakan bahwa mahasiswa tidak terbiasa menuliskan kembali soal cerita ke dalam tahapan: Apa yang diketahui, Apa yang ditanya, Bagaimana cara penyelesaiannya atau rumus apa yang digunakan, mahasiswa juga jarang memeriksa kembali apakah sudah benar hasilnya? Hasil ini menjadi bekal ketika mengajarkan materi himpunan setelah UTS.

Pada awal perkuliahan setelah UTS, yaitu tanggal 15 Oktober 2019, pembelajaran Himpunan, dilaksanakan dengan cara mengaktifkan mahasiswa menggunakan metode tanya jawab. Dosen mengingatkan kembali tentang himpuan dan operasi-operasi pada himpunan dengan cara melemparkan pertanyaanpetanyaan misalnya mana yang termasuk himpunan dan mana yang bukan himpunan. Apa saja operasi dari Himpunan. Berikan contoh untuk masing-masing operasi himpunan. Untuk menjawab pertanyaan tersebut, ada saja mahasiswa yang acungkan telunjuk untuk menjelaskannya di depan kelas. Banyak soal yang diberikan dipapan tulis termasuk soal cerita tentang himpunan yang harus ditulis ke dalam Diagram Venn. Soal cerita ini untuk menyelesaikannya sudah diawali dengan apa yang diketahui, apa yang ditanya, dan bagaimana penyelesaiannya. Untuk memantapkan pemahaman mahasiswa maka diberikan kasus, tentang makanan kesukaan mahasiswa yang terdiri dari: Bakso, Sate, atau Martabak Telur. Ketua kelas diminta mengumpulkan informasi dengan cara melemparkan pertanyaan tentang siapa yang suka makan Bakso, Sate atau Martabak Telur, kemudian mahasiswa harus acungkan tangan bila kesukaannya disebut. Ketua kelas menghitungnya. Informasi tersebut harus dituangkan ke dalam himpunan dan operasi himpunan serta diterjemahkan ke dalam diagram Venn. Berikut ini tentang himpunan.

\section{Himpunan}

Himpunan merupakan kumpulan benda atau objek yang didefinisikan dengan jelas. Lambang untuk simbul himpunan adalah huruf besar, misal A, B, C, dan lain sebagainya. Untuk menyatakan anggota dari sebuah himpunan adalah $\in$. Sedangkan untuk menyatakan anggota yang tidak termasuk dalam sebuah 
himpunan adalah $\notin$. Untuk menyatakan banyaknya anggota suatu himpunan A dinotasikan dengan n(A). (Martono dan Krisna, 1993).

\section{Operasi Dasar Himpunan}

Tabel 1. Operasi Himpunan

\begin{tabular}{|l|l|l|}
\hline Operasi Himpunan & $\begin{array}{l}\text { Gabungan } \mathrm{A} \cup \mathrm{B}=\{\mathrm{x} \mid \mathrm{x} \in \\
\mathrm{A} \text { atau } \mathrm{x} \in \mathrm{B}\end{array}$ \\
\hline $\begin{array}{l}\text { b. } \\
\text { dan } \mathrm{x} \in \mathrm{B}\}\end{array}$ & $\begin{array}{l}\mathrm{A} \cap \mathrm{B}=\{\mathrm{x} \mid \mathrm{x} \in \mathrm{A} \\
\text { dan } \mathrm{x} \text { bukan anggota } \mathrm{A}\}\end{array}$ \\
\hline $\begin{array}{l}\text { A }-\mathrm{B}=\{\mathrm{x} \mid \mathrm{x} \in \mathrm{A} \text { tetapi } \\
\text { bukan anggota } \in \mathrm{B}\}=\mathrm{A} \cap \mathrm{B}\end{array}$ \\
\hline
\end{tabular}

Sumber (Martono dan Krisna, 1993), (Sugiyono, tt), (Yuksinau. 2019) https://id.wikipedia.org/wiki/Himpunan_(matematika)

\section{Kemampuan Pemecahan Masalah}

Matematika dikenal sebagai ratu ilmu karena hampir semua persoalan mulai dari yang mudah sampai yang rumit dalam kehidupan sehari-hari bisa dipecahkan dengan bantuan matematika. Misalnya untuk menghitung berapa ekor ayam, atau itik atau kambing di suatu kandang, digunakan matematika. Ruseffendi (2006) mengemukakan bahwa kemampuan pemecahan masalah amat penting dalam matematika, bukan saja bagi mereka yang kemudian hari untuk mendalami atau mempelajari matematika, melainkan juga bagi mereka yang akan menerapkannya dalam bidang studi lain dan dalam kehidupan sehari-hari.

Kemampuan pemecahan masalah matematika yang digunakan dalam penelitian ini yaitu merujuk pada prosedur (Polya, 1973), (Polya, 1957). Berikut ini beberapa langkah yang perlu diperhatikan dalam proses penyelesaian masalah, yaitu: (1) bagaimana siswa memahami masalah; (2) bagaimana siswamenyusun rencana penyelesaian; (3) bagaimana siswa melaksanakan rencana penyelesaiannya; dan (4) bagaimana mengevaluasi hasil dan penyelesaian yang dibuat.

Secara garis besar tahap-tahap penyelesaian masalah menurut Polya ada 4 langkah yang digunakan sebagai landasan dalam memecahkan suatu masalah, dapat diuraikan sebagai berikut (Polya, 1973), (Polya, 1957). (1) Memahami Masalah. Pada aspek memahami masalah, siswa perlu mengidentifikasi apa yang diketahui, apa saja yang ada, jumlah, hubungan dan nilai-nilai yang terkait serta apa yang sedang mereka cari. (2) Membuat Rencana. Pada aspek ini, siswa perlu mengidentifikasi operasi yang terlibat untuk menyelesaikan masalah yang diberikan. (3) Melaksanakan Rencana. Pada aspek ini, hal yang diterapkan tergantung pada apa yang telah direncanakan sebelumnya, mengartikan informasi yang diberikan kedalam bentuk matematika, dan melaksanakan rencana selama proses dan perhitungan yang berlangsung. (4) Memeriksa Kembali. Pada tahap ini hal yang perlu diperhatikan adalah mengecek kembali informasi yang penting, mengecek semua perhitungan yang sudah terlibat, mempertimbangkan apakah solusinya logis, melihat alternatif lain, dan membaca pertanyaan kembali dan bertanya kepada diri sendiri apakah pertanyaannya sudah benar-benar terjawab.

Pada tanggal 29 Oktober 2019 setelah mahasiswa belajar tentang sistem bilangan real. Mahasiswa diminta untuk melakukan operasi himpunan terhadap 
himpunan dalam bilangan real. Setelah itu dilakukan postes. Soal postes serupa dengan soal pretes. Ada pergantian angka yang dilakukan untuk mengantisipasi agar mahasiswa tidak menyalin catatannya tentang soal pretes. Dosen sebelumnya bercerita bahwa soal pretes mereka bahas di kelas. Berikut ini adalah soal postes yang diambil dari buku Matematika 1 oleh (Martono, dan Hasibuan, 1993)

Suatu survey terhadap 1100 orang yang memakai tapal gigi diperoleh data seperti berikut:

300 orang menggunakan Segarharum

400 orang menggunakan Cemerlang

200 orang menggunakan Gigikilat dan Cemerlang

500 orang menggunakan Gigikilat

200 orang menggunakan Cemerlang dan Segarharum

100 orang menggunakan Gigikilat dan Segarharum

70 orang menggunakan ketiga jenis pasta gigi itu

Jawablah pertanyaan berikut.

a. Berapa orang yang hanya menggunakan satu jenis pasta gigi saja?

b. Berapa orang yang hanya menggunakan Cemerlang atau gigikilat tetapi tidak segarharum?

c. Berapa orang yang menggunakan tidak lebih dari dua jenis pasta gigi?

Gambar 1. Soal Cerita Tentang Himpunan (Martono dan Krisna, 1993)

Berdasarkan teori pemecahan masalah oleh Polya maka tahapan dari pemecahan masalah dari soal cerita himpunan di atas adalah seperti tabel 2 berikut.

Tabel 2 Tabel Pemecahan Masalah Soal Cerita Himpunan

\begin{tabular}{|l|l|l|}
\hline No & \multicolumn{1}{|c|}{$\begin{array}{c}\text { Tahapan } \\
\text { Pemecahan } \\
\text { Masalah Polya }\end{array}$} & \multicolumn{1}{|c|}{ Indikator } \\
\hline 1 & Memahami Masalah & $\begin{array}{l}\text { Mahasiswa mampu menuliskan dalam lambang } \\
\text { himpunan informasi tentang apa yang sudah } \\
\text { diketahui }\end{array}$ \\
\hline 2 & Membuat Rencana & $\begin{array}{l}\text { Mahasiswa mampu membuat rumus tentang } \\
\text { hubungan masing-masing informasi dalam bahasa } \\
\text { himpunan }\end{array}$ \\
\hline 3 & $\begin{array}{l}\text { Melaksanakan } \\
\text { Rencana }\end{array}$ & $\begin{array}{l}\text { Berdasarkan informasi no 2 mahasiswa mampu: } \\
\text { Membuat diagaram Venn a, b, dan c dengan } \\
\text { Menjawab pertanyaan a, an } \\
\text { menggunakan lambang operasi pada himpunan }\end{array}$ \\
\hline 4 & Memeriksa Kembali & $\begin{array}{l}\text { Mahasiswa mampu memeriksa kembali jawaban yang } \\
\text { telah dibuatnya sehingga tidak ditemukan kesalahan } \\
\text { seperti kurang teliti dalam melakukan operasi } \\
\text { tambah ataukurang. }\end{array}$ \\
\hline
\end{tabular}

Setelah lembar jawaban diperiksa ternyata banyak kesalahan yang dilakukan mahasiswa. Ini menunjukkan bahwa mahasiswa belum mampu menyelesaikan permasalahan himpunan dengan baik dan benar. Untuk itu dipandang perlu untuk melakukan penelitian dengan cara menganalisis kemampuan pemecahan masalah mahasiswa dari lembar jawaban mahasiswa dengan bantuan tahapan pemecahan masalah oleh Polya.

\section{Metode}

Metode penelitian yang dilakukan adalah menggunakan penelitian ex post facto, yaitu menurut Sugiyono (2012) ex post facto merupakan suatu penelitian yang 
dilakukan untuk meneliti peristiwa yang telah terjadi dan kemudian merunut ke belakang untuk mengetahui faktor-faktor yang dapat menimbulkan kejadian tersebut. Subjek penelitian adalah mahasiswa semester 1 kelas B Program Studi Pendidikan Matematika FKIP UNIB TA 2019/2010 yang berjumlah 33 orang.

Analisis menurut kamus Besar Bahasa Indonesia yaitu penyelidikan terhadap suatu peristiwa (karangan, perbuatan, dsb) untuk mengetahui kesalahan yang sebenarnya (sebab-musabab, duduk perkaranya, dsb). Analisis adalah kemampuan merinci suatu kesatuan kedalam bagian-bagian sehinga struktur keseluruhan dapat dipahami dengan baik (Dimiyati dan Mujiono, 2006). Adanya kesalahan-kesalahan yang dilakukan siswa dapat terjadi karena hambatan yang dialami siswa pada saat belajar. Kesalahan timbul akibat adanya kesulitan dan kekeliruan siswa dalam belajar. Menurut Kamus Besar Bahasa Indonesia, kesalahan adalah perihal salah, kekeliruan dan kealpaan.

Analisis yang digunakan adalah tahapan pemecahan masalah oleh Polya (1973) yang terdiri dari: Memahami masalah; 2) Membuat rencna; 3) Melaksanakan rencana; 4) Mmeriksa kembali. Indikator keberhasilan menyelesaikan soal cerita himpunan yaitu: 1) kemempuan mahasiswa menulis apa yang diketahui dalam bahasa himpunan, 2) kemampuan mahasiswa membuat rumus untuk menghitung informasi yang ada pada langkah 1; 3) membuat diagram Venn berdasarkan langkah1) dan langkah 2); 4) lukis diagram Venn; kemampuan mahasiswa menjawab pertanyaan dengan melakukan operasi himpunan; dan ketelitian mahasiswa melakukan operasi hitung

\section{Prosedur Penelitian}

Prosedur penelitian dapat dilihat pada gambar berikut ini:

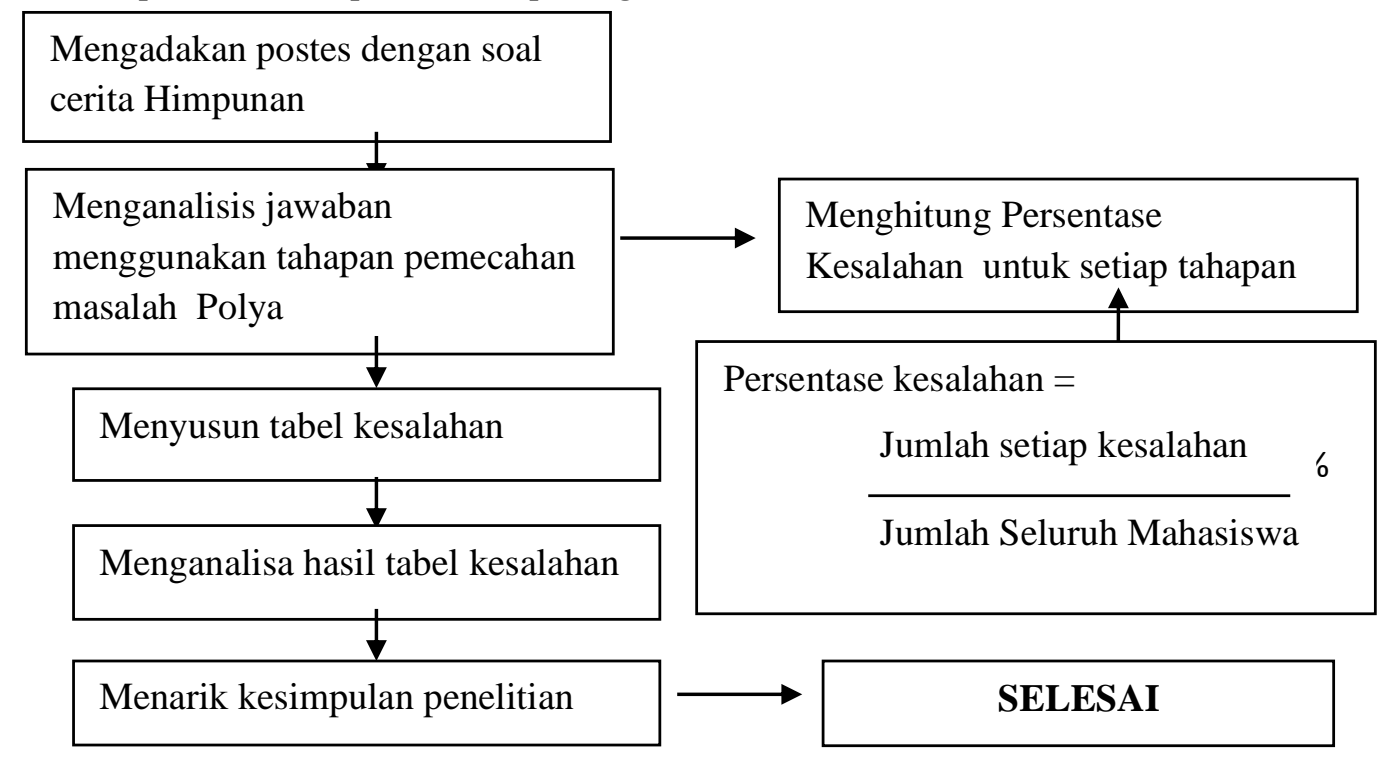

Gambar 2. Prosedur Penelitian

\section{Hasil}

\section{Hasil Postes.}

Gambar 3 berikut ini adalah hasil postes soal cerita tentang himpunan yang dimuat pada gambar 1 . Pada gambar 3 pada sumbu $\mathrm{x}$ terlihat ada: $\mathrm{x} 1, \mathrm{x} 2, \ldots \mathrm{x} 33$, itu adalah kode mahasiswa. Pada sumbu y terlihat ada angka 0, 20,..100 itu adalah rentang nilai postes. 


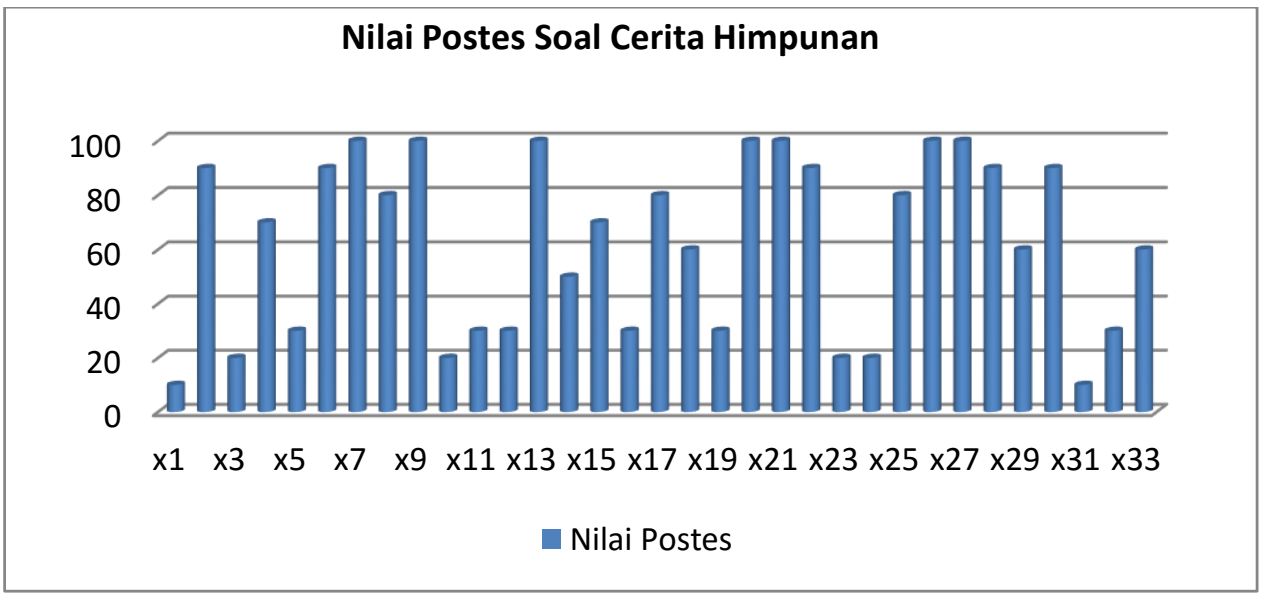

Gambar 3 Nilai Postes Mahasiswa Tentang Soal Cerita Himpunan

Berdasarkan gambar 3 terlihat bahwa beberapa orang mahasiswa memperoleh nilai sempuna yaitu seratus. Beberapa orang mahasiswa memperoleh nilai sangat kecil yaitu 10. Nilai rata-rata mahasiswa $=61,82$. Yang memperoleh nilai $\geq 80$ adalah $45,45 \%$ dan termasuk kategori cukup efektif. Hasilnya sudah jauh lebih baik dari hasil pretes. Tabel 3 berikut ini adalah hasil pengelompokkan jawaban mahasiswa tentang soal cerita himpunan.

Tabel 3 Prosentase Jenis Jawaban Mahasiswa

\begin{tabular}{|l|l|l|l|}
\hline \multirow{2}{*}{ SOAL } & \multicolumn{3}{|c|}{ JAWABAN (\%) } \\
\cline { 2 - 4 } & Benar & Kosong & Salah \\
\hline Cerita Himpunan & 21,21 & 6,06 & 72,73 \\
\hline
\end{tabular}

Berdasarkan Tabel 3 terlihat bahwa ada 72,73\% mahasiswa yang melakukan kesalahan dalam memecahkan soal cerita himpunan. Hasil langkah Polya berikut ini tidak hanya dilakukan pada lembar yang salah, tetapi juga pada lembar jawaban yang benar. Artinya seluruh lembar jawaban di periksa. Setelah jawaban dianalisis semuanya menggunakan tahapan Polya diperoleh hasil seperti yang tertera pada Tabel 4 berikut.

Tabel 4 Hasil Analisis Pemecahan Masalah Soal Cerita Himpunan

\begin{tabular}{|c|c|c|c|}
\hline No & $\begin{array}{l}\text { Tahapan } \\
\text { Pemecahan } \\
\text { Masalah } \\
\text { Polya }\end{array}$ & Indikator & $\begin{array}{l}\text { Prosentase Kesalahan } \\
\text { Mahasiswa menyelesaikan } \\
\text { Soal Cerita Himpunan (\%) }\end{array}$ \\
\hline 1 & $\begin{array}{l}\text { Memahami } \\
\text { Masalah }\end{array}$ & $\begin{array}{lr}\text { Mahasiswa } & \text { mampu } \\
\text { menuliskan dalam lambang } \\
\text { himpunan informasi } \\
\text { tentang apa yang sudah } \\
\text { diketahui }\end{array}$ & $\begin{array}{llr}\text { - } & \text { ada } 66,67 \% & \text { tidak } \\
\text { menuliskan apa yang } \\
\text { diketahui } \\
\text { ada 33,33\% menuliskan } \\
\text { apa yang diketahui }\end{array}$ \\
\hline 2 & $\begin{array}{l}\text { Membuat } \\
\text { Rencana }\end{array}$ & $\begin{array}{lrr}\text { Mahasiswa } & \text { mampu } \\
\text { membuat } & \text { rumus } & \text { tentang } \\
\text { hubungan } & \text { masing-masing } \\
\text { informasi } & \text { dalam } & \text { bahasa } \\
\text { himpunan } & & \end{array}$ & $\begin{array}{l}100 \% \text { mahasiswa tidak } \\
\text { menuliskan rumus umum } \\
\text { untuk membantu pembuatan } \\
\text { diagram Venn. }\end{array}$ \\
\hline 3 & $\begin{array}{l}\text { Melaksanakan } \\
\text { Rencana }\end{array}$ & $\begin{array}{l}\text { Berdasarkan informasi no } 2 \\
\text { mahasiswa mampu: } \\
\text { - Membuat diagaram } \\
\text { Venn } \\
\text { - Menjawab pertanyaan } \\
\text { a, } \\
\text { Menjawab pertanyaan } \\
\text { b, dan }\end{array}$ & $\begin{array}{l}\text { - } 100 \% \text { mahasiswa langsung } \\
\text { melukis diagram Venn } \\
\text { beserta isinya; } \\
\text { Untuk menjawab } \\
\text { pertanyaan a, b, c, pada } \\
\text { soal cerita himpunan, } 100 \\
\% \text { menjawab langsung } \\
\text { berdasarkan gambar }\end{array}$ \\
\hline
\end{tabular}




\begin{tabular}{|c|c|c|c|}
\hline & & $\begin{array}{l}\text { - Menjawab pertanyaan c } \\
\text { dengan menggunakan } \\
\text { rumus operasi pada } \\
\text { himpunan }\end{array}$ & $\begin{array}{l}\text { diagran Venn., tampa } \\
\text { menjelaskan rumus operasi } \\
\text { himpunan yang digunakan } \\
\text { untuk menghitungnya.. }\end{array}$ \\
\hline 4 & $\begin{array}{l}\text { Memeriksa } \\
\text { Kembali }\end{array}$ & $\begin{array}{lr}\text { Mahasiswa } & \text { mampu } \\
\text { memeriksa } & \text { kembali } \\
\text { jawaban yang } & \text { telah } \\
\text { dibuatnya sehingga tidak } \\
\text { ditemukan } \\
\text { seperti kurang teliti dalam } \\
\text { melakukan operasi tambah } \\
\text { atau kurang. }\end{array}$ & $\begin{array}{l}\text { ada } 72,73 \% \text { tidak melihat } \\
\text { kembali jawaban yang sudah } \\
\text { mereka kerjakan }\end{array}$ \\
\hline
\end{tabular}

Berdasarkan Tabel 4 terlihat bahwa hampir semua mahasiswa menulis jawaban tanpa menulis apa yang diketahui dan dikaitkan dengan penulisan himpunan. Hampir semua mahasiswa mejawab pertanyaan tanpa menuliskan rumus himpunan yang digunakan. Mereka langsung menuliskan diagram Venn. Kemudian menjawab pertanyaan a,b dan c dalam bentuk angka-angka yang mereka ambil dari diagram Venn. Gambar 4 berikut merupakan contoh jawaban postes oleh mahasiswa yang tidak dilengkapi dengan langkah penyelesaian soal cerita himpunan.
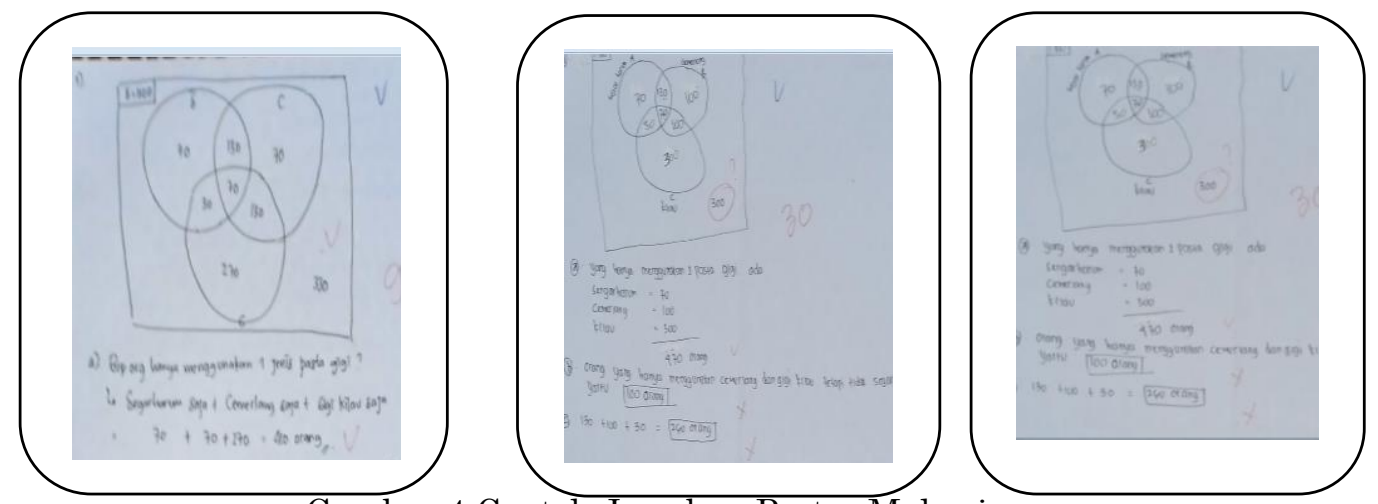

Gambar 4 Contoh Jawaban Postes Mahasiswa

Setelah lembar jawaban diperiksa, dan ternyata untuk membuat diagram Venn, mahasiswa langsung mengisi angka-angka pada diagram Venn tanpa penjelasan darimana datangnya angka-angka tersebut. Langkah perbaikan yang dilakukan adalah melalui pesan WA meminta mahasiswa menjawab kembali soal cerita himpunan di rumah dan dikumpulkan jelang kuliah tanggal 5 Oktober 2019. Mahasiswa diminta menjawab dengan lengkap sesuai tahapan pemecahan masalah Polya dengan tahapan: 1) menuliskan apa yang diketahui ke dalam lambang himpunan; 2) membuat rumus himpunan secara umum tentang himpunan semesta dan himpunan bagianya serta komplemen dari himpunan bagian; 3) Menggunakan rumus tersebut untuk membuat diagram Venn. Menggunakan rumus operasi himpunan yang tepat. dan diagram Venn untuk menjawab pertanyaan, a, b, dan c; 4) meminta mahasiswa agar membiasakan diri untuk memeriksa kembali jawaban yang telah dibuat. Berikut ini adalah salah satu jawaban mahasiswa lengkap dengan langkah untuk mendapatkan nilai. 


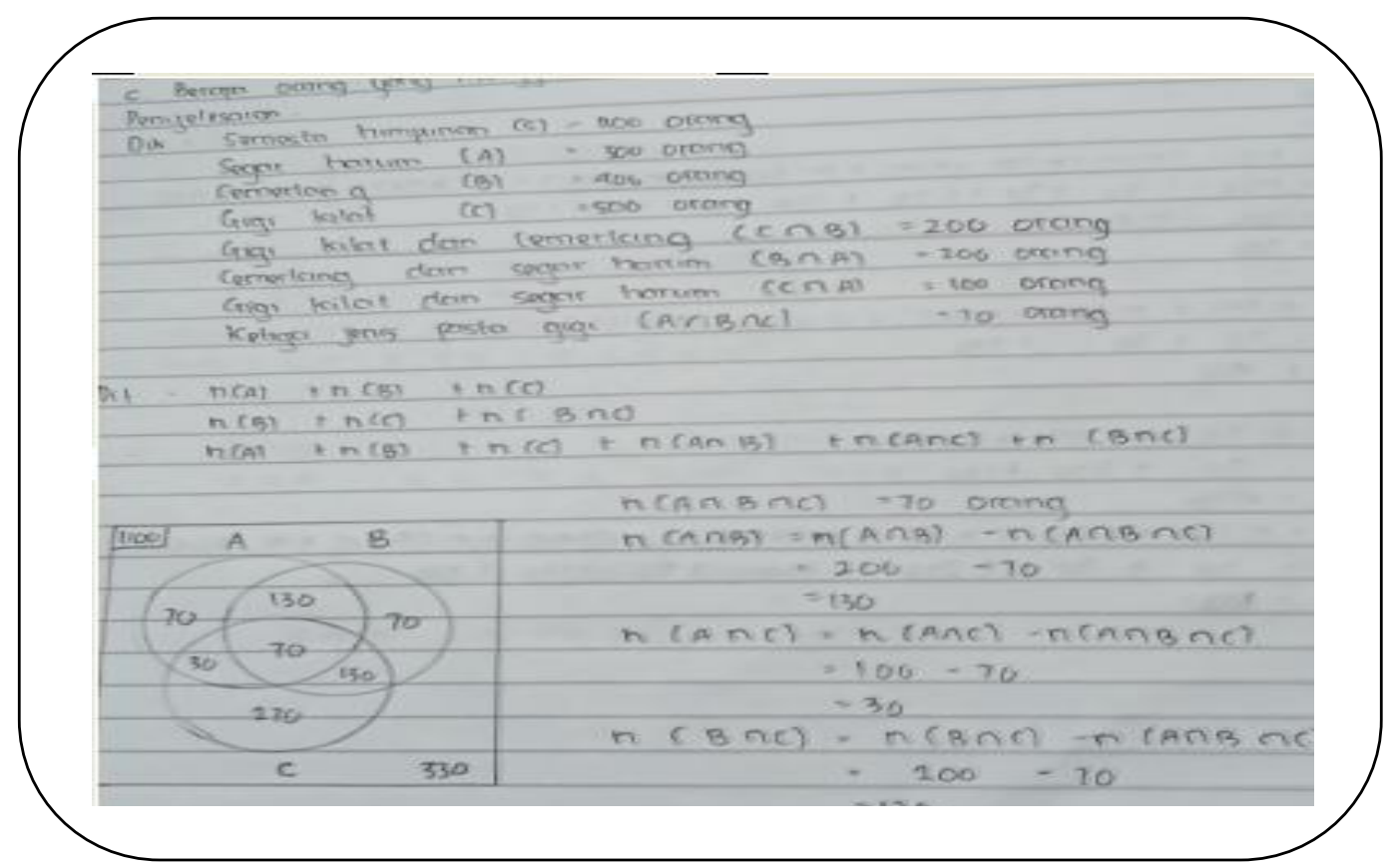

Terlihat pada gambar 5 bahwa mahasiswa telah menuliskan lambang himpunan untuk memperoleh nilai atau angka yang akan diisikan pada diagram Venn. Untuk menjawab pertanyaan a,b, dan c mahasiswa juga telah menggunakan operasi himpunan yang bersesuaian. Kalau dilakukan analaisa pemecahan masalah berdasarkan tahapan Polya. Mahasiswa sudah bisa melaksanakannya.

Pesan WA untuk menjawab ulang soal cerita himpunan juga dilengkapi dengan pertanyaan "Jelaskanlah dengan ringkas mengapa saudara menjawab soal cerita himpunan memilih jalan pintas artinya tidak kelihatan darimana angka jawaban tersebut diperoleh". Setelah data dikumpulkan diperoleh informasi sebagai berikut:

- $24,24 \%$ mahasiswa mengatakan bahwa sejak SMA mereka terbiasa menjawab dengan singkat, tepat dan teliti.

- 36,36 \% mahasiswa mengatakan bahwa mereka menghitung dikertas buram, tetapi tidak menyalin ke lembar jawaban karena tidak cukup waktu bila setiap langkah disalin

- $\quad 39,39 \%$ mahasiswa mengatakan untuk menghemat waktu langsung mengisi langsung.

Berdasarkan informasi di atas dapatlah diambil pelajaran bahwa kebiasaan menjawab soal cerita dimasa SMA sulit diubah bila dosen tidak menuntut jawaban yang lengkap. Ketika di SMA atau SLTA soal ujian lebih banyak berbentuk pilihan ganda dengan jumlah soal yang banyak. Hal ini membuat siswa harus berlatih menjawab dalam waktu singkat, tepat dan teliti. Ketika soal berbantuk essay, ternyata kebiasan di SLTA masih terbawa.

Kalau dicermati tahapan pemecahan masalah menurut Polya, terlihat bahwa langkah tersebut sangat sistematis. Kalau mahasiswa sudah terbiasa bekerja secara sitematis tersebut, soal cerita yang lebih sulit dari himpunan akan bisa diselesaikan dengan tuntas, asalkan ada rumus yang dipakai untuk membantu menyelesaikan soal tersebut. Para pendidik juga dengan mudah bisa memberikan bantuan kepada mahasiswa, pada tahapan apa mahasiswa kesulitan dalam memecahkan masalah.

Kebiasan memecahkan masalah secara sistematis seperti yang dilakukan Polya bila diterapkan sejak dibangku Sekolah Dasar akan besar pengaruhnya kepada siswa. Soal cerita olimpiade yang sulit-sulit tersebut, akan bisa diselesaikan 
oleh siswa. Bila hal ini dapat jadi kebiasaan mahasiswa atau siswa, maka akan tertata pola pikir mahasiswa atau siswa dalam menyelesaikan soal cerita apapun nantinya dengan tuntas.

Sejalan dengan pendapat diatas, Baiduri (2015) menyimpulkan bahwa secara umum setiap tahapan Polya yang dilakukan siswa SMP dalam pemecahan masalah geometri berpengaruh positif terhadap ketuntasan belajarnya. Secara khusus aktivitas yang sangat berpengaruh pada ketuntasan belajar pada tahapan Polya adalah:

a) Pada tahap memahami masalah, aktivitas mencoba untuk memahami masalah sebelum menyelesaikannya dan memahami masalah sebelum mencoba menyelesaikannya sangat berpengaruh dalam ketuntasan belajar.

b) Aktivitas mencoba untuk menentukan apa yang diperlukan dalam menyelesaikan masalah pada tahap membuat rencana pemecahan masalah berpengaruh besar dalam ketuntasan belajar.

c) Aktivitas memahami apa yang harus dilakukan dan bagaimana menerapkannya secara pasti pada tahap melaksanakan rencana pemecahan masalah berpengaruh besar dalam ketuntasan belajar.

d) Aktivitas memeriksa solusi yang telah dikerjakan pada memeriksa kembali berpengaruh besar dalam ketuntasan belajar

Berdasarkan kajian teori, hasil penelitian dan pembahasan penelitian, Supriadi, Mardiyana, dan Subanti (2015) menyimpulkan:

1. Siswa dengan tingkat kecerdasan emosional tinggi: a) mampu memahami masalah dengan menggunakan proses berpikir pembentukan pengertian, b) mampu membuat rencana pemecahan masalah dengan menggunakan proses berpikir pembentukan pendapat, c) mampu melaksanakan rencana pemecahan masalah yang telah direncanakan dengan menggunakan proses berpikir pembentukan kesimpulan atau penarikan kesimpulan, d) mampu memeriksa kembali jawaban

dengan menggunakan proses berpikir pembentukan kesimpulan atau penarikan kesimpulan.

2. Siswa dengan tingkat kecerdasan emosional sedang: a) mampu memahami masalah dengan menggunakan proses berpikir pembentukan pengertian, b) mampu membuat rencana pemecahan masalah dengan menggunakan proses berpikir pembentukan pendapat, c) mampu melaksanakan rencana pemecahan masalah yang telah direncanakan dengan menggunakan proses berpikir pembentukan kesimpulan atau penarikan kesimpulan, d) mampu memeriksa kembali jawaban dengan menggunakan proses berpikir pembentukan kesimpulan atau penarikan kesimpulan.

3. Siswa dengan tingkat kecerdasan emosional rendah: (a) tidak lengkap dalam memahami masalah karena mengalami ketidaksempurnaan proses berpikir pembentukan pengertian, (b) tidak lengkap dalam membuat rencana pemecahan masalah karena ketidaksempurnaan proses berpikir pembentukan pendapat, ketidaksempurnaan proses pembentukan pendapat, (c) ketidaksempurnaan dalam membuat rencana pemecahan masalah mengakibatkan siswa tidak dapat menjawab dengan benar, siswa tidak sempurna melaksanakan proses berpikir pembentukan kesimpulan dan pembentukan kesimpulan dengan sempurna, (d) mengalami ketidaksempurnaan dalam memeriksa kembali jawaban karena ketidaksempurnan dalam proses berpikir pembentukan kesimpulan.

\section{Kesimpulan}

Secara umum setelah dilakukan analisis pemecahan masalah soal cerita himpunan, dapat disimpulkan bahwa mahasiswa cendrung mengambil jalan pintas untuk menyelesaikan masalah soal cerita. Kesalahan yang dilakukan mahasiswa kadang tidak bisa diketahui oleh penilai apa penyebab kesalahannya. Tidak 
mengerti atau tidak teliti dalam operasi himpunan atau operasi aritmatika Kebiasaan ini mungkin karena sewaktu sekolah, penilaian dilakukan dalam bentuk soal pilihan ganda.

\section{Referensi}

Baiduri, 2015. Pengaruh Tahapan Polya Dalam Pemecahan Masalah Terhadap Ketuntasan Belajar

Geometri Siswa Sekolah Menengah Pertama. Jurnal Pendidikan

Matematika Volume 6 Nomor 1 Januari 2015. Universitas Muhammadiyah Malang.

Dimiyati dan Mudjiono (2006). Belajar dan Pembelajaran. Jakarta: PT. Rineke Cipta

Martono dan Krisna. 1993. Matematika 1. Untuk Ilmu-ilmu Pertanian, Kehidupan dan Perilaku.

Gramedia Pustaka Utama. Jakarta

Polya, G. 1973. How to Solve It (2nd ed.). Princeton, New Jersey: Princeton University Press.

Polya, G. 1957. "How to Solve It", 2nd ed., Princeton University Press, ISBN 0-69108097-6

Ruseffendi, E. T. (2006). Pengantar Kepada Membantu Guru Mengembangkan Kompetensinya dalam Pengajaran Matematika untuk Meningkatkan CBSA. Bandung: Tarsito. Retrieved from http://onesearch.id/Record/IOS3107.10571

Sugiyono. 2012. Metode Penelitian Kuantitatif Kualitatif dan R\&D. Bandung. Alfabeta

Sugiyono. Tt. Matematika: TEORI HIMPUNAN . http://staff.uny.ac.id/dosen/dr-irsugiyono-mkes

Supriadi, Mardiyana, Subanti. 2015. Analisis Proses Berpikir Siswa Dalam Memecahkan Masalah

Matematika Berdasarkan Langkah Polya Ditinjau Dari Kecerdasan Emosional Siswa Kelas

Viii Smp Al Azhar Syifa Budi Tahun Pelajaran 2013/2014. Jurnal Elektronik Pembelajaran Matematika ISSN: 2339-1685 Vol.3, No.2, hal 204-214 http://jurnal.fkip.uns.ac.id

Wikipedia. Tt. https://id.wikipedia.org/wiki/Himpunan_(matematika) diakses tanggal 31 oktober 2019

Yuksinau. 2019. Himpunan Matematika. https://www.yuksinau.id/himpunanmatematikal 